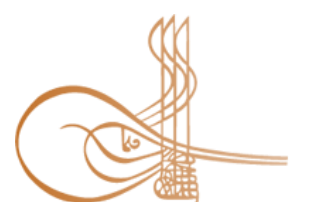

www.turkishstudies.net/social
Turkish Studies - Social Sciences

eISSN: 2667-5617

Research Article / Araștırma Makalesi

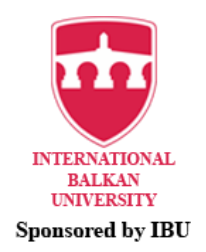

Sponsored by IBU

\title{
KİT Tecrübelerinden Türkiye Varlık Fonuna Bakış
}

\author{
A perspective to the Turkey Wealth Fund from the experience of SOE
}

\author{
Resül Yazıcı** $^{* *}$
}

\begin{abstract}
In their historical processes, the interventions to the economy during their development efforts of the states took place in different forms. Inherently, it was observed that the implementation results were also not equally successful. In other words, public interventions necessary or inevitable for a period and, successful public administration practices, were later criticized for various reasons. As a result of failures or inevitable changes due to mistakes made in practice, intervention shapes have changed. Therefore, the market and public authority should not exclude each other, that is, interventions should not be unlimited; but they should be done at the right time, on the right place and in an appropriate manner. For this, policies that increase public revenues and transparency practices that ensure fiscal discipline should be implemented. As a method, privatization practices have become fashionable in public enterprises where professional management was not included; the establishment of a legal and institutional infrastructure, which is the sine qua non of the market economy, was aimed; independent regulatory and supervisory institutions have been created for businesses to operate effectively and efficiently. After the proclamation of the Republic, SOEs that came to the agenda as the necessity of realization the development through the state, has been established, as a necessity of the economic structure of that period, particularly due to deficiencies in the financial and physical capital stock. In the 1960s, the SOEs, which filled an important gap in the implementation of the import substitution development strategy, had relative success. Turkey must use its accumulated institutional memory effectively. In particular, in the establishment and operation of projects like the Turkey Wealth Fund, the experiences of structures such as the Privatization Administration, the Savings Deposit Insurance Fund, the Banking Regulation and Supervision Agency, the Competition Authority must be considered. After the global crisis, the uncertainty and destructive competition environment triggered by globalization, is making the management of operations both in financial institutions and businesses, increasingly difficult. The need for the public is increasing due to several reasons, such as: trade wars caused especially by the shrinking market volume in globalizing markets; migration movements caused by wars triggered by global powers; technological developments with an unpredictable future; global disasters experienced in the natural environment and the facts revealed by coronavirus disease (Covid-19), which is also a global threat. However, these structures should not be bulky, because in previous periods application problems and operating errors in SOEs and similar enterprises could be ignored for a period, but today there is no such margin of tolerance. The objective of this study is, after examining basic economic policies and the institutions
\end{abstract}

\footnotetext{
* Bu çalışmada makale yazarının Türkiye'deki KİT’lerin Özelleştirilmesi ve Satış Yöntemleri adlı Yüksek Lisans Tezinden de yararlanılmıştır.

** Dr. Öğretim Üyesi, Bilecik Şeyh Edebali Üniversitesi, İktisadi ve İdari Bilimler Fakültesi, İktisat Bölümü

Asst. Prof. Dr, Bilecik Şeyh Edebali University, Faculty of Business Administration and Economics, Department of

Economics

ORCID 0000-0002-7875-3331

resul.yazici@bilecik.edu.tr

Cite as/ Atıf: Yazıcı, R. (2020). KìT tecrübelerinden Türkiye Varlık Fonuna bakış. Turkish Studies - Social, 15(4),

2199-2218. https://dx.doi.org/10.29228/TurkishStudies.42884

Received/Geliş: 13 April/Nisan 2020

Accepted/Kabul: 20 June/Haziran 2020

Copyright (C INTAC LTD, Turkey
} 
exerted by the Turkish Republic for its development efforts, and determining in which cases it has been successful or unsuccessful, to develop recommendation for the future.

Structured Abstract: From the past to present the interventions of states to the economy according their development efforts have been realized in different ways. Naturally, it was observed that the implementation results were also not equally successful. In other words, public interventions that were necessary or inevitable for a period and successful public administration practices, were later criticized for various reasons. Basically, as a result of failures or inevitable changes due to mistakes made in practice, intervention patterns have changed. Therefore, the market and public authority should not exclude each other, that is, interventions should not be unlimited, but they should be done at the right time, on the right place and in an appropriate manner. The purpose of this is to implement policies that increase public revenues and transparency practices that ensure fiscal discipline. As a method, privatization practices have become fashionable in public enterprises where professional management was not included; to establish a legal and institutional infrastructure, which is the sine qua non of the market economy, was aimed; and independent regulatory and supervisory institutions have been created for businesses to operate effectively and efficiently. After determining what has been tried to be done from past to present, and in which cases it has been successful or unsuccessful; the aim of the study is to develop recommendations for the future by examining the basic economic policies and the institutions that the Turkish Republic since its establishment to present has applied for development efforts.

After the proclamation of the Republic, the establishment of SOEs (State Owned Enterprises) has come on the agenda, because of the necessity to realize the development through the state. SOEs started to be established due to the economic difficulties at that period, especially the insufficiencies in the financial and physical capital stock. The SOEs, which filled the important gap in the implementation of the import substitution development strategy in the 1960s, had relative successes. One of the important reasons for the failure of the import substitution development strategy in Turkey was the prescription of the IMF, which came up with the shortage of foreign currency problem, because due these prescriptions privatizations were made. Especially in 2001, while the IMF recipe was being implemented, it was passed from the fixed exchange rate regime to the floating exchange rate regime after the crisis, which was mainly caused by the fact that the public debt stock could not be turned. This situation led to the confiscation of banks, especially those which were unable to handle the open position risk, because they could not fulfill their commitments. Although this program of IMF and the confiscation status afterwards are debatable, important institutional structures have been gained in terms of reformation in the financial sector.

Since the emergence of the 2008 global financial crisis led to the confiscation of bankrupt banks and the expropriation of companies, it was inevitable for the public enterprises option to come to the agenda again. In this period, especially in the financial sector, it was observed that the risk imposed by the private sector should be balanced by the public. However, SOEs were opposed due to the strengthening of the private sector during the periods when markets worked well.

Justifiable reasons of the establishment of SOEs in Turkey, business failures in the post despite their success, the experiences during the privatization process, and also the institutional capacity acquired with the 2001 crises, are very important. Due to the following issues that have recently been on the agenda, this institutional capacity and institutional memory should be taken into account in the redesign of SOEs and similar organizations:

- The necessity of the state to re-enter the markets in different ways, especially due to problems caused by the lack of supply in food and livestock products.

- The necessity of increasing the state's share due to coup attempts in Turkey and security issues in our region.

- Most importantly the increasing need for public, due to the facts revealed by the coronavirus disease (Covid-19), because in the global system all countries are seeking for solutions on their own.

Therefore, Turkey must use its accumulated institutional memory effectively. In particular, the experiences of structures such as the Privatization Administration, the Savings Deposit Insurance Fund, the Banking Regulation and Supervision Agency, the Competition Authority must be considered in the establishment and operation of projects like the Turkey Wealth Fund. Because the uncertainty and destructive competition environment triggered by globalization in today's world, makes it increasingly difficult to manage

Turkish Studies - Social, 15(4) 
operations both in financial institutions and businesses. The need for the public is increasing due to several reasons, such as: trade wars caused especially by the shrinking market volume in globalizing markets; migration movements caused by wars triggered by global powers; technological developments with an unpredictable future; global disasters experienced in the natural environment and the facts revealed by coronavirus disease (Covid-19), which is also a global threat. However, these structures should not be bulky, because in previous periods application problems and operating errors in SOEs and similar enterprises could be ignored, but today there is no such margin of tolerance. A difficult period has started for all businesses.

Keywords: Macroeconomic, Development, Public Economic Enterprises, Privatization, Independent Regulatory and Supervisory Institutions, Sovereign Wealth Funds, Financial System

Öz: Tarihsel süreçlerinde devletlerin kalkınma çabalarında ekonomiye müdahaleleri farklı şekillerde gerçekleşmiştir. Doğal olarak uygulama sonuçlarında da aynı derece devamlı başarılı olunmadığı görülmüştür. Diğer bir ifadeyle, bir dönem gerekli veya kaçınılmaz olan kamu müdahaleleri, başarılı kamu işletmeciliği uygulamaları, sonrasında çeşitli gerekçelerle eleştirilmiştir. Temel olarak uygulamada yapılan hatalarla yaşanan başarısızlıklar veya kaçınılmaz değişimler sonucunda müdahale şekilleri değişmiştir. Bunun da gereği piyasa ve kamu otoritesi birbirini dışlamamalı yani müdahaleler sınırsız olmamalı fakat doğru zamanda, tam yerinde ve uygun bir şekilde yapılmalıdır. Bunun da amacı kamu gelirlerini artırıcı politikaları, mali disiplini sağlayıcı şeffaflık uygulamalarını devreye almaktır. Yöntem olarak, profesyonel yönetimin yer almadığı kamu işletmelerinde özelleştirme uygulamaları moda olmuş, piyasa ekonomisinin olmazsa olmazı hukuksal ve kurumsal altyapının oluşturulması amaçlanmış, işletmelerin etkin ve verimli çalışabilmesi için bağımsız düzenleyici ve denetleyici kurumlar oluşturulmuştur. Cumhuriyetin ilanından sonra Türkiye’de, kalkınmanın devlet eliyle gerçekleştirilmesinin gerekliliği olarak gündeme gelen KİT’ler, dönemin iktisadi yapıdaki zorunlulukları, özelikle finansal ve fiziksel sermaye stokundaki yetersizlikleri nedeniyle kurulmaya başlamıştır. 1960'lı yılarda da, ithal ikameci kalkınma stratejisinin uygulanmasında önemli boşluğu dolduran KIT'lerin göreceli başarıları olmuştur. Türkiye bu anlamdaki birikmiş olan kurumsal hafızasını etkin bir şekilde kullanmalıdır. Özellikle, Özelleştirme İdaresi Başkanlığı, Tasarruf Mevduatı Sigorta Fonu, Bankacılık Düzenleme ve Denetleme Kurumu, Rekabet Kurumu gibi yapıların tecrübeleri, Türkiye Varlık Fonu gibi projelerin tesisinde, çalıştırılmasında dikkate alınmalıdır. Zira küresel kriz sonrasında, küreselleşmenin de tetiklediği belirsizlik ve yıkıcı rekabet ortamı, hem finans kuruluşlarında hem de işletmeler de operasyonların yönetimini giderek zorlaştırmaktadır. Özellikle küreselleşen piyasalardaki daralan pazar hacminin neden olduğu ticaret savaşları; küresel güçlerin tetikleyerek sebep olduğu savaşların ortaya çıkardığı göç hareketleri; geleceği öngörülemeyen teknolojik gelişmeler; doğal çevrede yaşanan küresel felaketler ve son şekli yine küresel bir tehdit olan koronavirüs hastalığının (covıd-19) ortaya çıkardığı gerçekler nedeniyle, kamuya duyulan ihtiyaç artmaktadır. Fakat bu yapıların hantal olmaması gerekmektedir. Çünkü önceki dönemlerdeki KİT ve benzeri işletmelerdeki uygulama sorunları, işletme hataları belli bir dönem görmezden gelinebilirken artık böyle bir tolerans marjı kalmamıştır. Bu çalışmanın da amacı, Türkiye Cumhuriyeti'nin tarihsel süreçteki kalkınma çabalarında uyguladığı temel ekonomi politikalarını ve kurumlarını inceleyerek, nerelerde başarılı veya başarısız olunmuş durumlarının tespitinden sonra gelecek için öneriler geliştirilmeye çalışmaktır.

Anahtar Kelimeler: Makro Ekonomi, Kalkınma, Kamu İktisadi Teşebbüsleri, Özelleştirme, Bağımsız Düzenleyici ve Denetleyici Kurumlar, Ulusal Varlık Fonları, Finansal Sistem

\section{Giriş}

Cumhuriyetin ilanından sonra Türkiye'de, kalkınmanın devlet eliyle gerçekleştirilmesinin gerekliliği olarak gündeme gelen Kamu İktisadi Teşebbüsleri (KİT), dönemin iktisadi yapıdaki zorunlulukları, özelikle finansal ve fiziksel sermaye stokundaki yetersizlikleri nedeniyle kurulmaya başlamıştır. Bu yetersizlerin çözümlenebilmesinde temel araç olan KİT veya benzeri uygulamalar, gelişmiş ekonomilerde de ortaya çıkan piyasa başarısızlıklarının; konjonktürün gerektirdiği stratejik sektörlere yatırım yapılması gerekliliğinin veya büyümenin devamlılığının sağlanması gibi gerekçelerle de kullanılmıştır. Fakat KITT'lerin sonraki dönemlerde artan zararları veya başka gerekçelerle, Türkiye'de de çeşitli nedenlerle kabul gören, 1980'lerdeki egemen liberal iktisat politikalarının çözümsel yaklaşımı özelleştirme olmuştur. 
$\mathrm{Bu}$ yaklaşım ışığında, kamu mülkiyetinin azaltılmasının birbirine bağlı temel gerekçelerini, yönetimin kamuda olmasının ortaya çıkardığı olumsuzluklar; finansmanın devlet tarafından karşılanmasının getirdiği sorunlar; yönetimini belirleyecek kriterlerin nesnel olmaması; değişikliklere gösterilemeyen uyum sonucunda oluşan zararlar şeklindeki varsayımları sıralayabiliriz. Bu gerekçelerle gündeme gelen özelleştirme uygulamalarının sağlıklı olmamasının temel nedenleri, uygulama öncesi ve sonrasındaki eksikliklerde yani mevzuat düzenlemelerindeki yetersizlikleri halletmeden gösterilen acelecilik sonucundaki sorunlarda görülmüştür. Dolayısıyla Türkiye'de gerek KİT'lerin kurulması, işletilmesi ve gerekse de tasfiyesi sürecinde yaşanan deneyimler; 2001 kriziyle edinilen kurumsal kabiliyet/hafiza ile elde edinilen tecrübeler ve bunların kullanılması önemli hale gelmiştir. Çünkü:

- Özellikle gıda ve hayvancılık ürünlerinde arz yetersizliğinden kaynaklanan sorunlar nedeniyle devletin yeniden piyasalara farklı şekillerde girmesi gerekmektedir.

- Türkiye'deki darbe girişimlerinin ve coğrafyadaki güvenlik sorunlarının zorunlu kıldığ yerli savaş sanayisinde kamunun payının artırılması zorunlu olmuştur.

- Son olarak, 2019 yılında bulaşıcı hastalığa neden olan yeni koronavirüs hastalığının (covıd19) ortaya çıkardığı ekonomik sorunlar da kamuya duyulan ihtiyacı artırmıştır.

$\mathrm{Bu}$ sayılan temel sorunlar nedeniyle artan ihtiyacın en uygun şekilde karşılanabilmesi için Türkiye Cumhuriyeti'nin tarihsel süreçteki kalkınma çabalarında edinilen tecrübeler dikkate alınarak ve bunlar revize edilerek hangi tür yapıların tesis edilebileceği, işletilebileceği önemli bir konu olmaktadır. Bu soruna cevap arayan çalışmada, Türkiye'deki KíT'lerle ilgili özelleştirmeye karar verildiği yıllardaki gerekçeler ve özelleştirme sürecinde edinilen tecrübeler 1şığında, gündeme gelen Türkiye Varlık Fonu'nun (TVF) başarılı bir şekilde nasıl işletilebileceği ve bu konuda yapılması gereken düzenlemelere yer verilmektedir. Bu çerçevenin referans alındığı çalışmada, Türkiye'de KİT'lerin kuruluş gerekçeleri, özelleştirme amaçları ele alındıktan sonra Türkiye ekonomisinin KİT ve özelleştirme tecrübelerinden alınacak derslere ve arkasından da Türkiye Varlık Fonu'nun etkin çalışabilmesi için politika önerilerine yer verilmiştir.

\section{Türkiye'de KİT’lerin Kuruluş Gerekçelerine Bakış}

Türkiye Cumhuriyeti'nin kalkınma çabalarına başladığı 1930'lu yıllarda temelleri atılan KİT benzeri uygulamalar, o yılların kendine has ekonomik ve sosyal yetersizliklerinin gereği olarak gündeme gelmiştir. Başka bir ifadeyle siyasal anlamda bir devletçilik değil, ülkenin ekonomik kalkınmasının acil ve zorunlu olduğu bilinciyle uygulanmıştır. Bu uygulamaya yönelik temelleri atılan KİT'lerin kuruluş amaçlarını şu şekilde sıralayabiliriz:

\subsection{Ekonomik Kalkınmayı Sağlamak}

Savaştan yeni çıkmış, beşeri, finansal ve fiziksel sermaye yetersizliği olan ekonominin, büyüme ve kalkınmasının sağlanmasında devletin önemli görevleri bulunmaktadır. Devletin müdahale etmediği durumda yani ekonomik kalkınmanın kendi haline bırakılması çok sakıncalıdır, içinde bulunulan her türlü sermaye eksikliğinin neden olduğu kısır döngünün kırılması imkânsızdır. $\mathrm{Bu}$ yüzden kalkınma sürecinin ilk aşamalarında devletin ekonomiye müdahalesi gerekli olmuştur. Başka bir ifadeyle bu müdahalenin gerekçesi sosyalist bir yaklaşım değildir. Pamuk'a (2014: 181) göre de, Genç Türkiye Cumhuriyeti'nin ekonomi politikası, özel sektöre dayalı bir model öngörüyordu. Ancak Ankara çevreleri ekonominin denetimini tümüyle piyasaya veya özel sektöre terk etmeye hazır ya da niyetli değillerdi. Zaten Ermeni ve Rum müteşebbislerinin yokluğunda, böyle bir rolü üstlenecek güçte bir özel sektör de ortalıkta görülmüyordu. Böyle bir ortamda milli iktisat politikalarını oluşturabilmek için 1923 yılının Şubat ayında, Lozan barış görüşmelerinin kesildiği dönemde İzmir İktisat Kongresi toplanmıştır. Pamuk (2014: 181), Ökçün'e (1968) göre Kongre'de somut içerikten çok, iç ve diş dünya kamuoyuna verilen sembolik mesajlar öne çıkmaktaydı. Yine 
de Kongre'nin 1929 Dünya Bunalımına kadar iktisat politikalarına egemen olan eğilimleri yansıttı̆̆ı söylenebilir.

1930'ların Dünya Bunalımı koşullarında Pamuk'a (2014: 181) göre, devletin ekonomi içindeki yeri sadece Sovyetler Birliği'nde değil, Avrupa'da ve Amerika'da da genişlemekteydi. Türkiye'de de 1929 sonrasında iç ve dış pazarlara daha fazla yönelmiş olan bölgelerin tarım kesiminde başlayan ve oradan kent ekonomisine sıçrayan güçlükler, devlet öncülüğünde sanayileşme stratejisinin benimsenmesinde çok önemli rol oynadı.

$\mathrm{Bu}$ sanayileşme sürecinde kamu teşebbüslerinin, modern teknolojiyi ülkeye getirmelerinin ve bunu uygulayacak teknik eleman yetiştirmelerinin rolü önemli olmuştur. Bu kuruluşların faaliyet gösterdiği sektörlerde (tekstil gibi) özel işletmecilik daha iyi gelişmiştir. Ayrıca temel yatırım ve tüketim mallarının kamu teşebbüsleri tarafından ülke içinde üretilmesi dışa bağımlılığı azaltmıştır (Görgün, 1973: 246).

\subsection{Müteşebbis Yetersizliğini Gidermek ve Onlara Yol Göstermek}

Genç Türkiye Cumhuriyeti'nde KİT'ler, Tezel'e (1986: 217) göre, devlet girişimciliğini özel girişimciliğin yerine değil, özel girişimciliği tamamlamak üzere kullanmayı amaçlıyordu. Birinci ağırlık devlet yatırım programlarının gerçekleştirilmesine tanınmış olsa da, özel sanayinin güçlendirilmesi hükümet politikasının bir parçasıydı. Bu nedenle sanayide devlet kapitalizmine başvurulmasından sonra da, özel sanayi birikimine doğrudan devlet desteği sağlanması sürdürülmüştü. Daha da önemli olan devletçiliğin kendisinin sanayi burjuvazisinin gelișmesi üzerindeki olumlu etkileriydi. Devlet yatırım programının uygulanması, birbiriyle ilişkili birçok endüstriyi eş zamanlı kurarak ve geliştirerek, Türkiye'de sanayi üretiminin sınırlarını genişletmiştir. Sanayinin yapısı farklılaşmıştır. Bu yatırımların, ekonomideki girdi-çıktı iliş̧kileri sistemi içinde çıktılarla ileriye ve girdilerle geriye yönelik çok sayıda uyarıcı etkisi olmuştur. Yatırımlar birçok özel firmaya dişsal yararlar sağlamıştır.

Yukarıda belirtilen fiziksel sermaye yatırımlarındaki artışın sağlanabilmesi için finansal sermaye ihtiyacının karşılanması gerekmekteydi. Bunun için de 1924 yılında kurulan İş Bankası, Kocabaşoğlu'na (2001) göre özel sektör ağırlıklı iktisat politikasının iyi bir örneğidir. Bankanın misyonu Türkiye'de özel sektörün desteklenmesi ve gelişmesi olarak özetlenebilir (Pamuk, 2014: 182).

\subsection{Dışsallıkları ve Tekel Problemini Çözmek}

Gerek her türlü sermayedeki yetersizlikler gerekse de topluma olumlu dişsallıklar sağlayan (eğitim, sağlık hizmetleri, altyapı yatırımları gibi) hizmetler için kamuya ihtiyaç duyulmaktadır. Aynı şekilde yüksek sermaye yatırımı gerektiren ve tekel durumu oluşturan faaliyet alanlarında ortaya çıkacak aşırı karın kamuya aktarılması için de KİT ve benzeri oluşumlara ihtiyaç vardır. Özellikle küresel ölçekte rekabet edebilmek için de işletmelerin ölçek ekonomisinden yararlanması gerekir. Türk'e (2014: 7) göre de, ölçek ekonomilerinin söz konusu olduğu sektörlerde (telekomünikasyon, havayolu ve demiryolu ulaştırması, elektrik üretimi ve dağıtımı gibi) özel sektörün yeterli sermayeye sahip olamaması, yeterli sermayeye sahip olanların da tekel olma olasılığının yüksek olması piyasa mekanizmasının işleyişini zora sokmaktadır. Dolayısıyla bu alanlarda devlet, piyasa ekonomisinin yetersizliğini telafi etmek için faaliyette bulunmaktadır. $\mathrm{Bu}$ amaçlara yönelik kurulan KİT ve benzerleri, Türkiye Cumhuriyeti'nin kuruluş yıllarında ve sonrasında, yukarıdaki amaçlarla üretimde ve ticarette yer alırken, aşağıdaki nedenlerle de bunlar özelleştirilmiştir.

\section{2. Özelleştirme Amaçlarına Bakış}

KİT'ler, Türkiye'de uygulanan korumacı iktisat politikalarıyla, bazen belli sektörleri teşvik etmek bazen de özel sektörün yer almadığı alanlarda bulunarak kalkınmanın motoru, sağladığı 
dışsallıklarla da özel sektörün destekçisi olmasına rağmen darboğazlarının zamanında çözülmemesi, biriktirilmesi, yenileşme ihtiyacının ertelenmesi gibi sorunlarla bir çıkmaza sokulmuşlardır.

Bu şekildeki davranışlardaki amaç özelleştirmeye gerekçeler oluşturmak olabilir ki, Tan'a (1992: 64) göre de özelleştirmenin kamu açıklarını kapatmak için kaynak yaratma aracı olarak kullanıldığı yönünde yaygın bir kanı bulunmaktadır. Bu amaca hemen kavuşmak için aceleci davranışlar da sergilenmiştir. Geçmiş özelleştirme uygulamalarına yönelik olarak bir başka önemli eleştiri konusu da, sağlam bir hukuksal ve yönetsel altyapı oluşturulmadan uygulamaya geçilmiş olması ve uygulamanın da açıklıktan yoksun bir biçimde yürütülmüş olmasıdır (Tan, 1992: 64).

Bunlara ilave olarak, siyasilerin ve/veya kamu yöneticilerinin yanlış politika ve popülist uygulamalarından kaynaklanan kamu kaynaklarının israf edilmesi özelleştirmenin temel gerekçeleri olmuştur. Özelleştirmeye gerekçe olan genel durum bu şekilde özetledikten sonra amaçları alt başlıklarda incelenecektir. Bu amaçların etkin işleyecek piyasa ekonomilerinde, hem piyasaların düzenlenmesi hem de işletmelerin sahip olması gereken özelliklerini ifade eden kısımları incelenecektir.

\subsection{Piyasa Ekonomisinin İşlerliğini Sağlamak}

Özelleştirmeye bir amaç olarak değil, KìT'lerin etkinlik ve verimlilik artışlarını sağlayan, ekonominin liberalleşmesine imkân veren ve ekonomik çarpıklıkları önleyen bir araç gözüyle bakılmalıdır. Yani özelleştirme sonrası piyasa ekonomisinin işlerliğini sağlayabilmek için piyasalarda rekabetçi ortamın oluşturulmasını ve tüketici haklarının korunmasını sağlayacak, özel sektörde yeni tekellerin oluşmamasını kontrol edecek üst kurulların oluşturulup, çalışmaları sağlanmalıdır.

$\mathrm{Bu}$ amaç, KİT’lerin olmadığı ekonomik yapılarda, piyasaların düzenlenmesini ve denetlenmesini sağlamak için daha da vazgeçilmezdir. Kamunun bu anlamdaki görevleri, özel sektörün başarılarını artırmak, aralarındaki ilişkilerin düzenlenmesini sağlamak için de çok önemlidir. Wade'e (1989: 15) göre de, özelleştirilmiş bir endüstri gerçek ekonomik özelliklerini daha kolay tanımlayabilir. Çünkü işletmenin görüşü, değişik bölümlerindeki çapraz sübvansiyonlarından veya ekonomik olmayan fiyat rejimlerinden ötürü bulanık hale gelmiştir. Bu bulanıklıkların ortadan kaldırılmasına yönelik önlemlerin alınması, işletme hedeflerinin daha belirgin hale gelmesine, endüstriyi yönetmedeki sorunların basitleşmesine olanak sağlayabilecektir. Çünkü popülist yaklaşımların olmaması, ticari ilkelerden yapılacak sapmaların açıklıkla ortaya konmasına imkân verebilecektir.

\subsection{Ekonomide Etkinlik ve Verimliliğin Artırılması}

Kamu girişimlerinin kanunla sağlanan tekel durumlarını, haksız rekabetini ortadan kaldırmak için gündeme getirilen özelleştirmenin başarısı, özelleştirme sonrası oluşturulacak rekabetçi bir piyasanın varlığına bağlıdır. Türk’e (2014: 19) göre KiT’ler, tekelci ya da tekel eğilimli yapılar olarak piyasayı kontrollerinde tutmaya çalışmaktadır. Bu kuruluşların zararları genel bütçeden karşılanmaktadır. Bu sayede tekelci yapılarının korunması sağlanmaktadır. $\mathrm{Bu}$ da ekonomik verimsizlikleri karşısında piyasadaki paylarını kaybetmemek için kaliteyi iyileştirmek, fiyat ya da maliyetleri düşürmek gibi bir çaba içine girmemeleri sonucunu doğurmaktadır. Tüm bunlar göz önünde bulundurulduğunda, özelleştirmeyle birlikte ekonomide rekabet ve verimliliğin artacağı beklenmektedir. Bu amacı güçlendirebilmek için, özel ile kamu sektörü arasında ayrım yapmayan ve her iki sektöründe eşit koşullarda rekabetini sağlayan politikaların izlenmesi gerekmektedir.

$\mathrm{Bu}$ nedenle özelleştirmeyle, liberalleştirmenin, rekabete etkileri açısından ayırt edilmesi gereği ortaya çıkmaktadır. Liberalleştirme, endüstrinin rekabete açılması anlamını taşır ve bir endüstri özelleştirildiği halde liberalleştirilmemiş olabilir. (...) Özelleştirmeden sektörü rekabete açarak liberalleştirmek ve sistemi rasyonelleştirmek de mümkün olabilmektedir (Erengül, 1989: 18). 
Ekonomide etkinliğin ve verimliliğin artırılması, sistemin rasyonelleştirilebilmesi; ekonominin popülist, plansız hükümet müdahalesinden (üst kurulların yönlendiriciliğinden değil) kurtarılması ve özel yatırımlar üzerindeki kamu harcamalarının sınırlayıcı, haksız rekabet yaratıcı (özellikle crowding-out etkisi ve kamu ihaleleriyle, sübvansiyonların rasyonel dağıttılmaması) etkilerinin kaldırılmasıyla sağlanacak disipline edilmiş bir piyasada mümkündür.

Piyasa aksaklıklarını ortadan kaldıracak, kaynak tahsisinde etkinliği ve verimliliği sağlayacak düzeni de Rekabet Kurumunun çalışmaları mümkün kılacaktır. Bu görevi T.C. Anayasasının 167. Maddesi şöyle düzenlemiştir: "Devlet, para, kredi, sermaye, mal ve hizmet piyasalarının sağlıklı ve düzenli işlemelerini sağlayıcı ve geliştirici tedbirleri alır; piyasalarda fiili veya anlaşma sonucu doğacak tekelleşme ve kartelleşmeyi önler”. Bu düzenlemeyle ilgili 4054 Sayılı Rekabetin Korunması Hakkında Kanun 13 Aralık 1994 tarihinde yürürlüğe girmiş ve Kanun'da öngörülen Rekabet Kurumu da 1997 yılında faaliyetlerine başlamıştır.

\subsection{Türk Sanayisinin Yeniden Yapılanmasını Sağlamak}

KİT'ler, Türkiye'de kalkınmanın motoru, sağladığı dışsallıklarla da özel sektörün destekçisi olmasına rağmen, yılların biriken sorunlarının, yenileşme ihtiyacının bilinçli veya bilinçsiz bir şekilde ertelenmesi, onları çıkmaza sokmuştur. Bu şekildeki uygulamalarla, Türk Sanayisinin yeniden yapılanmasını sağlamak görevini tamamlar duruma getirilmeleri ve/veya bu işi yapacak özel sektörle rekabet edemez duruma gelmeleri kaçınılmaz olmuştur. Dolayısıyla özelleştirme ile özel sektörün yapabildiği alanlardan çekilmiş olunması, kaynakların heba edilmemesini sağlayabilecek ve böylece kamu kaynakları özel sektörün girmediği diğer öncelikli alanlara yönlendirilebilecektir.

$\mathrm{Bu}$ alandaki görevin bir kısmını özel sektör işletmeleri yapabilir olmasına rağmen çeşitli nedenlerle yeterli olamamaktadır. Özellikle bilgi teknolojilerindeki hızlı değişimin etkileriyle dijitalleşen ekonomilerin biçim değiştirmesi, iş ortamlarının, yönetim şekillerinin buna ayak uyduramaması, sanayi toplumundan bilgi toplumuna dönüşüm olarak adlandırılan üretim yapısındaki sistemsel değişimler, küresel ekonomi olgusunun önemli göstergeleri olmuştur. Bu yeni ekonomide;

- Dünya daha erişilebilir olmakta.

- Fiziki olarak bulunulan mekândan bağımsız olarak sanal ortamların da iş hayatına hâkim olması, küresel iş yapma firsatlarını ortaya çıkarmakta. Tabii ki, bu teknolojilere sahip olan vizyonlu işletmeler de ve yönetimler de bu değişiklikler mümkün olacaktır.

Gerek koronavirüs hastalığının ve gerekse sanallaşan dünyanın zorunlu kıldığı iş yapma şekillerindeki değişiklikler, ekonominin veya yaşamın her alanında bilinen ezberleri değiştirecektir. Dijitalleşmeyle birlikte hızla değişen iş yapma şekilleri ve piyasa gerçeklerinde, hem kamunun direkt veya ortaklık şeklinde; hem de özel sektörün çağdaş işletmecilik anlayışıyla üretimlerini gerçekleştirmeleri daha da önemli olmaya başlamıştır. Çok önceden başlayan bu sürecin etkileri son yıllarda her alanda etkilerini daha fazla göstermektedir. Özellikle iş dünyasında yaşanan küresel ölçekteki rekabette başarılı olunmasını, bu teknolojilere hâkim olma seviyeleri belirleyecektir. Dolayısıyla Türkiye'de son dönemdeki şekliyle TVF yatırımları, alt başlıklardaki öneriler sonrasındaki yapılanmayla, bu şekildeki alanlara yönelebilmelidir.

\section{Öneriler \\ 3. Türkiye Ekonomisinin KİT ve Özelleştirme Tecrübelerinden Alınacak Dersler ve}

Türkiye Cumhuriyeti'nin gerek kuruluşunda gerekse de ithal ikameci kalkınma stratejisinin uygulanması sürecinde önemli eksiklikleri gideren, hem sayıları hem de ülke ekonomisi içindeki ağırlığı artan KİT’lerin başarılarına karşın 1980'lerin sonlarından itibaren çeşitli özelleştirme faaliyetleriyle kamu işletmeciliği cezalandırılmaya başlamıştır. $\mathrm{Bu}$ cezalandırmanın haklı nedenlerini: yönetimin hükümette olmasının ortaya çıkardığı sorunlar; finansmanın kamu tarafindan karşılanmasının sebep olduğu olumlu/olumsuz durumlar, değişikliklere yavaş uyum şeklinde 
sıralayabiliriz. Fakat özelleştirme uygulamalarının amacına uygun olmaması, uygulama öncesi ve sonrasında gösterilen acelecilikle karşılaşılan başarısızlıklar da, maruz kalınan maliyetleri yükseltmiştir. Bundan sonraki dönemlerde önemli olan aynı hataların yapılmaması, gerekli derslerin alınmasidır.

\subsection{KITT Tecrübelerinden Alınacak Dersler}

Türkiye'nin kurtuluş savaşından sonraki yapısının imarında büyük görevleri yerine getiren KİT'lerin, ekonomik ve siyasi nedenlerle gerçekleştirilen özelleştirmelerinde başarılara karşın hatalar da yapılmıştır. Bunları aşağıdaki ana başlıklarda şu şekilde özetleyebiliriz:

- Özelleştirilen KİT'lerin hepsi verimsiz çalışan ve kamuya yük olan işletmeler değildi.

- Dolayısıyla verimli çalışan, gelir elde eden işletmelerin özelleştirilmesinin, kamunun borç stokunu azaltmasının dışsallıkları unutulmamalı.

- Gerekli destekler verilmediği için zarar eden işletmelerin, çoğunun uzun süren tasfiye sürecinin maliyetleri de unutulmamalı. Bu aşamaya gelinmeden önce gerekli müdahaleler zamanında yapılabilmeliydi.

Tablo 1: Özelleştirme Fonu Kaynak Kullanım Tablosu (1986-Ekim 2019)

\begin{tabular}{|c|c|c|c|c|c|c|c|c|c|c|c|}
\hline $\begin{array}{c}\text { (Milyon ABD } \\
\text { Doları) }\end{array}$ & $\begin{array}{l}1986- \\
2010 \\
\end{array}$ & 2011 & 2012 & 2013 & 2014 & 2015 & 2016 & 2017 & 2018 & 2019 & Toplam \\
\hline $\begin{array}{l}\text { Hazineye } \\
\text { Aktarımlar }\end{array}$ & 29.716 & 1.341 & 825 & 4.540 & 3.502 & 2.305 & 3.697 & 2.588 & 1.158 & 489 & 50.161 \\
\hline $\begin{array}{l}\text { İlgili } \\
\text { Kuruluşlara } \\
\text { Aktarımlar }\end{array}$ & 1.595 & 215 & 188 & 1.186 & 702 & 35 & 21 & 18 & 19 & 4.653 & 3.983 \\
\hline $\begin{array}{l}\text { İstihdam } \\
\text { Ödemeleri }\end{array}$ & 471 & 18 & 11 & 31 & 18 & 8 & 5 & 4 & 5 & 2 & 573 \\
\hline $\begin{array}{l}\text { İlan-Reklam- } \\
\text { Danışmalık } \\
\text { Giderler }\end{array}$ & 183 & 5 & 9 & 8 & 5 & 5 & 3 & 3 & 2 & - & 223 \\
\hline Diğger Giderler & 13 & 27 & 3 & 3 & 3 & 2 & 27 & 16 & 16 & 2 & 318 \\
\hline $\begin{array}{l}\text { Kuruluşlara } \\
\text { Sermaye } \\
\text { Ödemeleri }^{1}\end{array}$ & 6.687 & 73 & 17 & 25 & 1.627 & 52 & 52 & 5 & 29 & 5 & 8.570 \\
\hline $\begin{array}{l}\text { Kuruluşlara } \\
\text { Borç Ödemeleri² }\end{array}$ & 2.624 & 610 & 89 & 2.979 & 1.187 & - & 58 & 54 & 28 & 46 & 7.389 \\
\hline $\begin{array}{l}\text { İdari Bütçeye } \\
\text { Aktarımlar }\end{array}$ & 123 & 11 & 11 & 12 & 10 & 8 & 9 & 8 & 7 & 5 & 204 \\
\hline Toplam Giderler & 41.617 & 2.298 & 975 & 8.783 & 7.054 & 2.415 & 3.873 & 2.589 & 1.264 & 554 & 71.422 \\
\hline \multicolumn{12}{|c|}{$\begin{array}{l}\text { AÇIKLAMALAR: } \\
\text { 1-"Sermaye Ödemeleri" ve "Borç Ödemeleri" kalemleri kaynağın ilk aktarım cinsi itibariyle yer almış olup, bilahare } \\
\text { yapılan sermaye mahsuplarını içermemektedir. } \\
\text { 2-Borçlanmalar (ticari bankalar, kapsam içi kuruluşlar, tahvil ve Hazine kredileri) ile borç geri ödemeleri (anapara+faiz) } \\
\text { ve Fon bakiyeleri rakamlara dâhil değildir. } \\
\text { 3-Rakamlar Nakit Giriş ve Çıkış rakamlarıdır. }\end{array}$} \\
\hline
\end{tabular}

Kaynak: ÖİB, 2020

- Türkiye'nin kendi imkânlarıyla marka yaptığı KİT'lerin, aceleci özelleştirme uygulamalarından elde edilen gelirlerle kamu borçlarının azaltılması amacının olumlu etkileri de unutulmamalıdır. Örneğin, Tablo 1'de Hazineye Aktarımlar kısmında görülen 50,161 milyon USD gibi bir bedel, özelleştirme gelirleriyle kamunun borç stokunun azalması, finansal sistemde faiz oranlarının düşüşüne, bu da hem enflasyon oranlarında; hem de kamunun bütçedeki faiz giderlerinde 
dolayısıyla bütçe açıklarında düşüşe yol açmıştır. $\mathrm{Bu}$ düşüş özellikle crowding-out etkisinin azalmasında da etkili olmuştur.

- Özellikle ne olursa olsun özelleştirme hemen gerçekleştirilsin şeklindeki yaklaşımlarla ortaya çıkan istihdam sorunlarının aşılabilmesi için erken emekliliğin teşvik edilmesiyle KİT'lerin maliyetleri daha çok artmıştır. Sosyal güvenlik sisteminde bugünlerde yaşanan aktüaryal dengenin bozulmasından kaynaklı sorunların temelinde, KITT'lere hem istihdam haznesi olarak bakılması hem de çalışanlara erken emeklilik hakkının verilmesi veya mecbur bırakılması yatmaktadır. Sosyal güvenlik sistemi Dama'ya (2018: 7) göre de, kapsam alanının genişliği cömert bir sosyal güvenlik anlamına gelirken prim ödemelerine dayalı finansmanı ve 2008'e kadar görülen çok başlılık sosyal güvenlik sisteminin gelir-gider dengesinde eşitsizliklere yol açmıştır. Bu eşitsizliğin derinleşmesinin nedenlerinin başında ekonomik yapı ve aktüeryal denge gözetilmeden çalışanların erken emekli edilerek aktif durumdan pasif hale geçirilmesi gelmektedir.

\subsection{KİT’ler ve Özelleştirme Tecrübelerinden Alınacak Dersler ve Politika Önerileri}

Türkiye'de 1980'li yılların ortalarında başlayan liberalleştirme hareketiyle, devletin ekonomiden çekilme kararı, özelleştirmede ilgili kurumsal yapıların kurulmasını, dış destekler alınmasını hızlı bir şekilde gündeme getirmişti. Hazırlatılan ve uygulamaya konulan planların amaçları ile uygulama sonuçları arasında (acele edildiği için) zıtlıklar, amaçlardan sapmalar ortaya çıkmıştır. TVF'nin yapılanma ve işletmecilik anlayışında aynı hataların yapılmaması için önemli dersler alınabilecek durumların bazıları aşağıdaki başlıklarda özetlenmiştir:

- Hayati bir sektör olan tarımda (Süt Endüstrisi Kurumu, Et ve Balık Kurumu gibi kurumlarda) özelleştirme hatalı olmuştur. Gerçi devlet bu kurumların faaliyetlerini ikame edecek uygulamalara gitmiştir. Fakat bunlar kalıcı çözümler değildir. Çünkü tahıl, sebze ve meyveler, süt ve süt ürünleri gibi temel gıda ürünlerinin arz ve talep seviyelerinde istikrar sağlanmalıdır. Bu ürünlerde yaşanan kıtlık veya arz fazlasının piyasa koşullarına bırakılması ilgili tarafları zor durumda bırakmaktadır. Dolayısıyla yaşanan enflasyon, deflasyon gibi ekonomik dengesizlikler bir şekilde müdahale edilmesi gereken alanlar olmaktadır. Zira koronavirüs hastalığı nedeniyle bu ürünlerde ihracatçı olan ülkelerin ihracatlarını yasaklaması gıda ürünlerinin stratejik önemini artırmaktadır. Bu son yaşananlar nedeniyle devletin vatandaşlarına dengeli, sağlıklı bir beslenmeyi ekonomik olarak karş1layabilecek şekilde üretim imkânlarının geliştirilmesini sağlaması görevi çok önemli olmaya başlamıştır. Türk'ün (2014: 194) verdiği şu öneri de, kooperatif bilincinin önem kazandığı tarım gibi bazı sektörlere de uyarlanabilir: Ekonomik etkinliği kalmamış, sosyal amaçlı olarak bölgesinde faaliyet gösteren kamu ișletmeleri (șeker fabrikaları, et kombinaları gibi) belirli bir program dâhilinde bölgesel kalkınma ajansları koordinasyonunda harekete geçirilecek yerel inisiyatiflere devredilebilir. $\mathrm{Bu}$ kuruluşlara yönelik yatırım ihtiyacının bir bölümü kalkınma ajansları kaynaklarından yapılacak aktarımlarla karşılanabilir. Bu yöntem, kalkınma ajansları politikasını destekleyici ve kalkınma ajanslarının gücünü artırıcı bir katkı da yapacaktır. Aynı zamanda, bölgesel paydaşların işletmeyi sahiplenmesiyle kuruluşların etkin çalıştııılarak merkezi yönetim üzerindeki yüklerinin ortadan kaldırılması sağlanabilir.

- KİT’lerin özelleştirilmesinde kullanılan blok satış yöntemiyle yabancı sermayenin gelişi, hem cari işlemler dengesine hem de işletmelerdeki yönetim kültürüne ve teknolojik gelişime olumlu katkı sağlamıştır.

- Özelleştirme kapsamındaki bazı KİT ve benzeri kuruluşların uzun zaman bu süreçte kalması, zorunlu veya yenileme yatırımlarını gerçekleştirememesi, işleyen/fabrika değerlerini ve pazar paylarını eritmiştir. Bu durum çeşitli sebeplerle Tasarruf Mevduatı Sigorta Fonu'na (TMSF) devredilen özel sektör işletmelerinde de yaşanmıştır. Bu durumların tekrar etmemesi için ülkenin kıt olan fiziksel sermayesinin, hurda değerine dönmemesine yönelik proaktif davranışların, stratejik planların hazır olması gerekir. 
- Ülkedeki ekonomik ve siyasi yapıdaki belirsizlikler nedeniyle ve acele edildiği için özelleştirme ihalelerinde uygun konjonktürün belirlenmesinde sıkıntılar yaşanmıştır. $\mathrm{Bu}$ da şirketlerin hesaplanan/belirlenen değeri ile el değiştirme değerlerini olumsuz etkilemiştir. Veya özelleştirilen şirketlere tekrar el konulmak zorunda kalınmıştır. Örneğin, özelleştirilen Sümerbank ve Etibank TMSF'ye devredilmiştir. Türkiye'nin ilk KITT'lerinden olan Etibank, Sümerbank gibi özel yasayla kurulmuş bankaların bu süreçleri yaşaması kötü olmuştur. Fakat özelleştirilmesine karar verilen diğer bankalarımızın da satışından vazgeçilmiş olmasının önemi bu günlerde görülmektedir. Kısacası Türkiye'nin kuruluş yıllarında yokları var eden; önemli reel sektör projelerine imza atan kurumların yaşatılması veya yenilerine imza atılması gerekmektedir.

- Özelleştirilen kuruluşların önemli bir kısmında, şirketin yeni sahipleri, yapılması gereken yeni yatırımlar yerine faaliyetlerinin tasfiye edilmesini tercih etmişlerdir. Bunun önemli bir nedeni, işletmelerin fabrikalarından daha çok gayrimenkullerinin farklı alanlarda değerlendirilmesinden önemli rant geliri elde etmeyi tahmin etmiş olmalarıdır. Elde edilen bu rant gelirlerinin hesaplanmasıyla, vergilendirilmesi yapılsaydı, özelleştirme gelirlerinde artış sağlanması sonucunda kamusal menfaat artırılabilirdi. Atiyas ve Oder'e (2008: 111) göre de, Değer Tespit Komisyonu tarafından 1999 ve 2002 yıllarında bağımsız uzman kuruluşlara yaptırılan değerleme çalışmalarını içeren üç ayrı değerleme raporundan, yıllar itibarıyla zarar eden dava konusu işletmenin arsa ve arazilerinin değerinin tesislerden daha yüksek olduğu anlaşılmaktadır. Bu tip işletmeler için uygun görülen değerleme yöntemlerinden biri işletmenin gayrimenkullerinin değerini gösteren tasfiye değeri yöntemidir.

- Özelleştirmenin ilan edilen amaçlarıyla çelişen uygulamalar yapılmış olması kurumlara duyulan güveni zedelemiştir. Örneğin hisse satışlarıyla, sermayenin tabana yayılarak, sermaye piyasalarının geliştirilmesi amaçlanmıştır. Fakat genelde blok satış yönteminin kullanılması, istisnai olan THY (Türk Hava Yolları) gibi küçük yatırımcıya yapılan özelleştirmelerde de, finansal okuryazarlığı yeterli olmayan küçük tasarruf sahiplerinin hisselerinin, büyük yatırımcılar tarafından düşük fiyatlardan toplanması gerçekleşmiştir. Bu da küçük tasarruf sahiplerinde, hem mağduriyet hem de sermaye piyasalarına kalıcı bir güvensizlik oluşturmuştur.

- Özelleştirme sürecindeki hazırlıklarda yapılan hatalar yüzünden ihalelerin yargı tarafından iptal edilmesi çeşitli mağduriyetlere neden olmuştur ${ }^{1}$.

- Bazı sektörlerin rekabete açılmadan özelleştirilmesinin gerçekleştirilmesi de, piyasa etkinliğinin ve verimliliğinin sağlanmasına olumsuz katkısı yapmıştır. Atiyas ve Oder'e (2008: 32) göre kamu hizmeti üreten doğal tekeller, son 20-25 yıla kadar çoğu ülkede kamu mülkiyeti altında örgütlenmiştir. Doğal tekellerin kamu mülkiyeti altında örgütlenmiş olmasının çeşitli nedenleri vardı. Belki en önemlisi, tekel gücünün yol açacağı zararları önlemektir. Bunun yanı sıra, kamu mülkiyeti altında evrensel hizmet hedeflerine daha rahat ulaşılacağına inanılmıştır. Çok az ülkede ise (başta ABD; Fransa'da su ve çöp gibi kimi hizmetler) bu tür hizmetler özel şirketler tarafından yerine getirilmiştir.

- Özelleştirmelerde, THY'deki özelleştirme yönteminde uygulanan Altın Hisse ${ }^{2}$ uygulaması iyi bir örnektir. Özelleştirmelerde veya Varlık Fonunun yer alacağı projelerde bu yöntemin

\footnotetext{
1 Özelleştirme işlemlerini iptal eden kararlarda şu tip sorunlara Atiyas ve Oder (2008) değinmektedir: İmtiyaz sözleşmesinin Danıştay denetiminden geçirilmemiş olması (Aktaş I, ENKA Doğalgaz); Rekabet ortamının sağlanmamış olması (Aktaş II, Tüpraş \%65.76 hisse satış1); Özelleştirme Kanunu'na veya şartnameye aykırı işlemler (Tüpraş, \%14.67 hisse satış1); Kapasite veya yatırım hedef veya taahhütlerinin belirlenmemiş olması (İskenderun Limanı, Seydişehir Alüminyum); Yanlış değerleme yönteminin kullanılmış olması (SEKA) vb.

${ }^{2}$ Uygulamada "altın hisse" olarak bilinen imtiyazlı pay 2001'de çıkarılan 4673 sayılı kanunla getirilmiştir. Kanunun gerekçesinde yer alan "telekomünikasyon hizmetlerinin milli güvenlik ve ulusal bağımsızlık hususlarındaki endişeler doğrultusunda Devlet tarafından tekel olarak yürütülmesi gerekliliği ortadan kalkmış, anılan hususların imtiyazlı hisse teşkili ile garanti altına alınması yeterli hale gelmiştir”. Açıklamasından anlaşılacağı üzere imtiyazlı hisse bu Anayasa Mahkemesi kararında dile getirilen endişeleri bertaraf etmeye yöneliktir (Atiyas ve Oder, 2008: 55).
} 
kullanılması, hem fona gelir akışı hem de kamunun stratejik sektörlerdeki gözetim ve denetim yetkisinin etkinliğini artırabilir.

- Bugünkü piyasa gerçeklerine bakıldığında şunlar da söylenebilir: Geçmişte yapılan kimi özelleştirmeler yerine kamunun bazı yatırımlarında kamu-özel işbirliği yöntemleri iyi bir alternatif olarak durmaktadır. Özel sektörün yönetim ve finansman imkânlarından faydalanma firsatı sağlayan bu ortaklık, kamuyu zarara uğratmayacak şekilde, kamunun vereceği garantilerinin hesabının çok iyi yapılması koşuluyla çoğu projelerde uygulanabilir. Türk'e (2014: 194) göre, DHMİ (Devlet Hava Meydanları İşletmesi) ve Savunma Sanayi Müsteşarlığına ait havalimanlarının terminal yatırımlarında, elektrik üretim santrallerinde, çeşitli karayolu ve liman yatırımlarında, sınır kapılarının modernizasyonlarının birçoğunda başarıyla uygulanan yap-ișlet-devret, yap-ișlet, ișletme hakkı devri gibi modelleri de içeren uygulama kapsamı farklı sektörleri de içine alacak şekilde genişletilebilir.

Özelleştirme uygulamalarındaki kurumsal kapasiteden yararlanılmasının öneminden bahsedilirken, Türkoğlu Karacaova $(2019,23)$ çalışmasında, özelleştirme ile TVF uygulamalarının farkına şu şekilde dikkat çekmektedir: Özelleştirme İdaresi Başkanlığının yanında yine onunla aynı olarak Başbakanlığa bağlı bir kuruluş olarak TVF'ye kamusal varlıklar aktarılmıştır. (Şu an ikisi de cumhurbaşkanlığı hükümet sistemi uyarınca Cumhurbaşkanlığına bağlıdır.) Ancak Özelleștirme İdaresinden farklı olarak TVF 4046 Sayılı Özelleştirme Uygulamaları Kanunu'na değil, özelde 6741 Sayılı kendi kuruluş kanununa genelde ise Türk Ticaret Kanunu'na tabi olmakla beraber kendi kuruluş kanununda da belirtildiği üzere kamusal varlıkların üzerinde her türlü tasarruf yetkisini haiz olduğu gibi bunların yönetimi dışında da faaliyette bulunabilmektedir.

\section{Türkiye Varlık Fonu'nun Etkin Çalışması İçin Öneriler}

Türkiye Cumhuriyeti'nin, KİT'lerini kurması, işletmesi ve sonrasındaki özelleştirme faaliyetlerinde edinmiş olduğu kurumsal hafiza, özellikle Özelleştirme İdaresi Başkanlığı, Bankacılık Düzenleme ve Denetleme Kurumu, Tasarruf Mevduatı Sigorta Fonu, Rekabet Kurumu gibi bağımsız düzenleyici/denetleyici yapıların kazandığı tecrübeler, yeni bir oluşum olan TVF'nin faaliyetlerinin planlanmasında, icrasında dikkate alınmalıdır. Çünkü her alanda küreselleşmenin de tetiklediği belirsizlik ve yıkıcı rekabet ortamı, özel veya kamu, hem finans kuruluşlarında hem de işletmelerde operasyonların yönetimini giderek zorlaştırmaktadır. Özellikle küreselleşen piyasalardaki daralan pazar hacminin neden olduğu ticaretteki çekişmeler; küresel güçlerin tetikleyerek sebep olduğu savaşların ortaya çıkardığı göç hareketleri; geleceği öngörülemeyen teknolojik gelişmeler; doğal çevrede yaşanan küresel felaketler ve son şekli yine küresel bir tehdit olan koronavirüs hastalığının ortaya çıardığı ekonomik sorunlar nedeniyle yeniden kamuya duyulan ihtiyaç artmaktadır.

Gerek artan küresel tehditler; gerekse de dijitalleşen dünyanın dayattı̆̆g yapay zekâ ürünlerinin zorunlu kıldığı iş yapma şekillerindeki değişiklikler ki, bunlara uyum sağlamada bazı kuşakların avantajına rağmen bazılarının elenmek zorunda kalması gibi sorunlar bilinen ezberleri değiştirecektir. Fakat nasıl bir değişim olacağı öngörülememektedir. Çünkü küreselleşmeden, modernleşmeden yararlanan çok uluslu şirketlerin kendi aralarında ortaya çıkan ticaret savaşlarıyla rekabet yapısının değişmesi, zorlaşmasına karşın koronavirüs hastalığı da işleri daha da zorlaştırmıştır. Dolayısıyla teknolojik gelişmelerden ve bunların sonucunda ortaya çıkan yeni çalışma ve iş yapma şekillerinden geride kalmanın maliyetleri çok yüksek olacaktır. Bu maliyetlere katlanmamak veya minimize etmek için kamu otoritesinin yönlendiriciliğine ihtiyaç artmaktadır. Bunun şekli, hem direkt veya ortaklık şeklinde işletmeci olarak; hem de düzenleyici/denetleyici şeklinde olabilecektir. Bu yüzden Türkiye Varlık Fonu Yönetimi Anonim Şirketinin ve Bağımsız Düzenleyici ve Denetleyici yapıların önemi daha da artmıştır. 


\subsection{KİT ve Benzeri İşletmelerin Yer Aldığı Ulusal Varlık Fonlarının Önemi}

Uluslararası Varlık Fonlarının (UVF) temel amacı Danık'a (2019: 4) göre, her geçen gün değişen dünyanın finans sisteminde ülkelerin resmi rezervleri (döviz-altın) dışında enerji, emtia ve finans sistemindeki gelişmeler doğrultusunda elde etmiş olduğu kazançları verimli bir şekilde kullanabilmektir. Ekonomik konjonktürde karşılaşılabilecek her türlü risk ve kriz ortamına karş1 mevcut varlıklarını koruyabilmek ve bu mevcut kaynakların devamlılığını sağlayarak ileriki nesillere sürdürülebilir kalkınma yolunda katkı sağlayabilmektir.

Gelecek nesiller için refahı ve tasarrufu arttırarak sürdürülebilir kalkınmaya destek olmak, makroekonomik politikalar doğrultusunda mali istikrarın sağlanması, yenilenemeyen emtia kaynaklarına ve bu kaynakların ihracatlarını çeşitlendirmek, sosyal ve iktisadi kalkınmaya destek olmakla birlikte alt ve üst yapı projelerine finansal kaynak oluşturmak da ulusal varlık fonlarının hedefleri arasında sayılabilmektedir. Karagöl ve Koç'a (2016) göre de, gelişmiş ve gelişmekte olan diğer ülkelerin ekonomilerine, yatırım ve tasarruflarına göre Türkiye'nin tasarruf oranları düşüktür. Bu noktada yapılması gerekli olan uygulamalar arasında son dönemde açıklanan TVF, Türkiye'nin ekonomik kalkınma hedeflerine ulaşmasında önemli bir adım olacaktır.

Bu kadar geniş bir yelpazedeki amaç şunu göstermektedir: Dijitalleşmeyle birlikte hızla değişen iş yapma şekilleri ve piyasa gerçeklerinde, hem kamunun direkt veya ortaklık şeklinde; hem de özel sektörün çağdaş işletmecilik anlayışıyla üretimlerini gerçekleştirmeleri daha da önemli olmaya başlamıştır. Demirtaş vd.'ne (2017) göre de, bir ülkenin gelişiminde önemli katkısı olan faaliyetlerden birisi, yenilikçi ürün ve hizmetleri, rakiplerden daha hılı bir şekilde piyasaya sunabilmektir.

$\mathrm{Bu}$ anlayışın hâkim olmasını sağlamak için yukarıda verilmeye çalışılan KíT'lerin özelleştirilmesinde yaşanılan deneyimler ve bu süreci yöneten yapılardaki kurumsal kapasite etkin ve verimli bir şekilde kullanılabilmelidir. Zira Türkiye'de bazı sektörlerde üretici veya tüketicinin aleyhine durumlar yaşanmasına yol açan arz ve talep dengesizliği ve özellikle koronavirüs hastalığının sebep olduğu ekonomik sorunların aşılması için piyasaların düzenlenmesi yanında gerekli sahalarda devletin doğrudan veya ortaklık şeklinde iştirak etmesi gerekmektedir. $\mathrm{Bu}$ anlamdaki bir diğer stratejik alan da savunma sanayidir ki, devletin direkt veya ortaklık şeklinde yatırım yapmasının zorunluluğu veya rekabet gücünün artırılmasını sağlamak gibi nedenlerle KİT veya benzeri uygulamalara ihtiyaç artmıştır. Fakat KİT'lerin yönetiminde geçmişte yapılan yani bir dönem özelleştirmenin gerekçesi olan hatalara tekrar düşülmeden bunlar yönetilebilirse; kurulan TVF ve bu fona bağlı alt fonların iştirak edeceği işletmeler Türkiye Ekonomisine önemli katkılar sağlayabilecektir. Durdu'ya $(2018,89)$ göre de, TVF'nin faaliyetleri yoğunlaştığ 1 takdirde "holding varlık fonu" statüsü için yeni tartışmalar ve araştırma alanları ortaya çıkacağı düşünülmektedir. Türkoğlu Karacaova $(2019,24)$ çalışmasına göre de, TVF özelleştirme usul ve esaslarından bağımsız olma yönünde hem bir aşamayı hem de bir aracı ihtiva eder ve bu anlamda yeni bir hukuki teknolojidir. Bir başka deyişle mevcut mevzuatta yer alan özelleştirme yöntemlerinden muaf tutularak ve tamamen özel hukuk alanındaki serbestiye sahip bir yapısal düzenleme haiz olarak Türkiye Kamusal Varlık Fonu, yeni ve her türlü kısıtlamadan azade bir özelleştirme yöntemidir.

$\mathrm{Bu}$ yasal gücün amacına uygun olarak kullanılabilmesi durumunun ne kadar önemli olduğunu Türk (2014) çalışmasında şu şekilde özetlemektedir: Bugüne kadar ülke içindeki rekabet düzeyini artırmak için kamu işletmeleri küçük parçalara ayrılıp özelleştirilirken, bundan sonraki süreçte dünya piyasalarında rekabet edebilecek güçlü şirketlerin oluşturulması stratejisinin göz önünde bulundurulması gereğine işaret edilmiştir. Özelleştirme uygulamalarında başarı sağlanabilmesi için piyasa ekonomisi müesseselerinin doğru şekilde kurulup etkin bir şekilde işletilmesinin yanında, özelleştirme üzerinde toplumsal mutabakatın sağlanması ve özelleştirmenin kurumsal ve hukuki altyapısının tesis edilmesi bir ön şart olarak ortaya çıkmıştır. 


\subsubsection{Türkiye Varlık Fonuna Genel Bakış}

26 Ağustos 2016 tarihinde kurulan Türkiye Varlık Fonu Yönetimi A.Ş.’nin kuruluş aşamasındaki temel amaçları şu şekilde belirtilmiştir. Sermaye piyasalarında araç çeşitliliği ve derinliğine katkı sağlamak, yurt içinde kamuya ait olan varlıkları ekonomiye kazandırmak, dış kaynak temin etmek, stratejik, büyük ölçekli yatırımlara iştirak etmek için TVF ve bu fona bağlı alt fonları kurmak ve yönetmek.

TVF’nin amaçları ve sahip olduğu portföye bakıldığında, ülke ekonomisini her türlü riske karşı korumak için stratejik önem arz eden sektör şirketlerine ve bunları geliştirebilmek amaciyla gerekli yetkiye sahip olduğu görülmektedir. 23 Ocak 2017 tarihli, 29957 Sayılı Resmî Gazete yayınlanan 684 numaralı KHK'nın 9. maddesine eklenen d bendine göre, “iktisadi devlet teşekküllerinden, bunların müessese, bağlı ortaklık, işletme, işletme birimleri ile varlıkları ve iştiraklerindeki kamu paylarından, sermayesinin tamamı veya yarısından fazlası Devlete ve/veya diğer kamu tüzel kişilerine ait olan ticari amaçlı kuruluşlardaki kamu paylarından, sermayesinin tamamı kamuya ait olan ticari amaçlı kuruluşların sahip olduğu hisse ve varlıklardan, Devletin diğer iştiraklerindeki kamu paylarından ve Hazineye ait paylardan Bakanlar Kurulu tarafından Türkiye Varlık Fonuna aktarılmasına veya Şirket tarafından yönetilmesine karar verilenlerden" oluşur şeklinde belirtilmiştir.

Son yapılan düzenlemeyle bu yetkilerin daha da genişletildiği görülmektedir. Düzenleme, 17 Nisan 2020 Tarihli Resmi Gazete yayınlanan 7244 sayll kanunun 15 ve 16. maddelerinde yer almıştır. Bu düzenleme ile 6741 sayılı Türkiye Varlık Fonu Yönetimi Anonim Şirketinin Kurulması ile ilgili kanunun bazı maddelerinde değişiklik ve ilaveler yapılmıştır. Düzenlemenin amacı TVF'nin, koronavirüs nedeniyle zor duruma düşen şirketleri satın alabilmesine veya bunlara ortak olabilmesine imkân tanımaktadır. Düzenlemedeki temel amaç stratejik ve büyük ölçekli şirketlerden sermaye çıkışının önlenmesini ve nakit sorunlarına çözüm sağlanmasını içermektedir. Son yapılan düzenlemelerin olumlu amaçlarına karşın nasıl başarılı olacağı konusundaki (en başta şeffaflık) endişeleri devam etmektedir.

$\mathrm{Bu}$ geniş ve yeniden artırılan yetkilere sahip olan TVF, ülkenin stratejik varlıklarını geliştirmek, değerlerini artırmak ve böylece stratejik öncelikli yatırımlar için kaynak sağlamayı amaçlamasının önemi bugünlerde daha hayati görülmektedir. Türkiye Varlık Fonuna, 5 Şubat 2017 tarihli 29970 sayılı resmi gazetede yayımlanan 2017/9756 sayılı karar ile birlikte özelleştirme kapsam ve programında bulunan şu varlıklar ve kuruluşlar devredildi: Ziraat Bankası, Türksat, BOTAŞ, BİST, Eti Maden, Türk Hava Yolları, PTT, Çaykur, Boru hatlarının hazineye ait olan hisseleri ve Halk Bankası'nın özelleştirme içerisinde bulunan programları ve payları bulunmaktadır.

TVF'nin sahip olduğu portföy ve diğer dünya uygulamalarına bakıldığında fonun bir kalkınma fonu özelliği vardır. Bu yüzden küresel sermayenin fona yeterli ilgiyi göstermesi için denetim ve şeffaflık konusundaki eksikliklerinin giderilmesi önemli görülmektedir. Bu eksikliklerin giderilmesi sonucunda fona veya bağlı alt fon ve şirketlerine yönelik kaynak akışı sayesinde TVF, Türkiye ekonomisi için önemli bir araç haline gelebilecektir veya gelmelidir. Çünkü Türkiye ekonomisinde tasarrufların yetersiz olması, bütçe ve cari hesaplarımızda da açık bulunması dışa bağımlılığımızı artırmaktadır. TVF'nin, Norveç Varlık Fonu'nun sahip olduğu emtia ve emtia dış1 ürünlerden elde edilen bir gelir fazlalığı da bulunmadığına göre portföydeki şirketlerin niteliği ve etkin çalıştırılması çok önemli olmaktadır.

Norveç Varlık Fonu (Sovereign Wealth Fund in Norway), ülkenin petrol kaynaklarından elde ettiği gelirlerden, bütçe fazlalıklarından oluşturulmuştur. Fonun temel amac1, ileride petrol gelirlerinde oluşabilecek dalgalanmaların önüne geçerek ülkenin gelir kaynaklarında istikrarı sağlayarak gelecek neslin refah düzeyini artırmaktır. Fon, yönetim, işleyiş, yatırım alanları ve denetim konusunda açık ve işlevleri yüksek bir UVF'dir. Bu yaklaşımla fon yapmış olduğu tüm yatırımları, aylık ve yıllık raporlarla kamuoyuna açık bir şekilde duyurmaktadır. Fonun bu tavrı, 
yatırımcılara güven aşılamakta ve akıllarda soru işaretlerinin oluşmasını engellemektedir. Kısacası Norveç Varlık Fonu, yönetim, işleyiş, denetim, yatırım ve şeffaflık ilkeleri açısından örnek alınabilecek önemli bir varlık fonudur (SWFI, 2020).

Norveç Varlık Fonu çalışma prensiplerinin benimsenmesi ve işletilmesi durumunda, TFV'nin kabul görmesi, kendini ispat etmesiyle gelecek yeni sermaye sayesinde, konjonktüre uygun, kısa dönemde gelir getirecek stratejik yatırımların yapılması da mümkün olacaktır. Fakat uzun dönemde gelir getirecek yatırımlara girişilmiş olması durumunda ortaya çıkacak küresel veya yerel ölçekteki krizler, hem TVF'yi hem de ulusal ekonomiyi olumsuz etkileyebilecektir. Bu yüzden, her türlü ani şok ve dalgalanmalar durumundaki sermaye çıkışlarına karşı tamponlar/rezervler bulundurulmalıdır. Bu amaçlara yönelik TVF'yi ve bünyesindeki şirketleri daha etkin bir hale getirmek için izlenmesi gereken yöntemler sıradaki başlıkta verilmektedir.

\section{Öneriler}

4.1.2. Türkiye Varlık Fonu ve Bünyesindeki Şirketlerin Etkin Çalışabilmesi İçin

Küresel rekabetin gittikçe şiddetlendiği piyasalarda ve koronavirüs hastalığının ekonomik faaliyetleri durma noktasına getirdiği gezegenimizde, finansal sermaye pastasından pay alma yarışında olan UVF'ler arasındaki rekabet de kaçınılmazdır. Bu yüzden küresel finans piyasalarından pay alabilmek için sistemin uluslararası standartlara uyumu da şarttır. Standartlara uyum konusunda dünyanın en başarılı ve lider fonu olan Norveç Varlık Fonu ${ }^{3}$ örnek alınabilir.

TVF’nin başarılı olmasının koşulları hakkında Çetinkaya $(2017,38)$ şu görüşleri ileri sürmüştür: TVF bir yatırım fonu olmakla beraber kamuya ait bir şirketler grubu olarak da düşünülebilir. Devletin üst düzey bürokratlarının ticari bir geçmişi yoktur. Ancak bu kurum tamamen ticari faaliyetler üzerine planlanmıştır. Fonun, profesyonel yönetimden kastedilen sanırım, tecrübeli ve profesyonel ticari geçmişi olan bir ekip tarafından yönetilmesi planlanmıştır. $\mathrm{Bu}$ durum büyük şirketlerin üst düzey yöneticilerinin transferleri ile yapılacak olursa, astronomik ücretler ödenmesi gerekebilir. Böylesine önemli bir görevi üstlenecek olan kişi veya kişilerin başarıları ve başarısızlıkları devlet memuru zihniyetiyle sorgulandığında bu görevi kimse kabul etmeyecektir. Tamamen performans esasına göre olması bu yönüyle doğru bir karar olarak kabul edilebilir. Ancak bu kişilerin nasıl seçileceği henüz açıklık getirilen bir durum değildir. Bu durum son derece suiistimale açık bir durumdur.

2008 küresel finans krizi döneminde, bu fonların nasıl başarılı olabileceğine ilişkin Ulusal Varlık Fon yöneticileri, Ekim 2008 yılında toplanarak, bu tür fonların uyması gereken ilkeleri, yirmi dört madde şeklinde, Santiago İlkeleri olarak yayınlamış (IWG, 2008). Türkiye Varlık Fonunun yasal altyapısında da, Santiago ilkelerinin bazıları görülmektedir. Bu ilkeler, ülkelerin kendisine bağlı ulusal varlık fonlarını ve bağlı şirketlerin nasıl yönetilmesi gerektiği konusundaki temel önerileri içermektedir. Bu ilkeler için daha geniş ölçekte şu da söylenebilir: Kamusal veya özel sermaye şeklindeki mülkiyet ayırımına gitmeden, tüm işletmeler, küresel ölçekte başarılı olabilmesi için bağımsız ve uzman bir bakış tarzını içeren Santiago ilkelerini uygulamak zorundadırlar. $\mathrm{Bu}$ ilkeler 1şı̆̆ında, küresel ölçekte kabul görmek için TVF'nin ve şirketlerinin başarılı olabilmesi için gerekli temel yönetim kriterlerinin neler olması gerektiği konusunda aşağıda verilen önerilerde Santiago İlkeleri'nde (IWG, 2008) yer alan maddeler esas alınmıştır:

- Her ülke farklı ekonomik ve siyasi yapıya sahiptir. Bu farklılık ülkelerin ulusal varlık fonlarının yatırım stratejilerini ve yönetim yapısını da etkileyecektir. Dolayısıyla UVF'nin yatırım amaçları açıkça belirlenmeli ve kamuoyuna açıklanmalıdır. Bu politikalar ve yatırım tercihleri arasındaki risk marjı dengeli olmalı ve fonun yönetimi sağlam portföy kriterlerine dayanmalıdır.

\footnotetext{
${ }^{3}$ Dünyadaki toplam varlıklara göre sıralamada otuz birinci fakat UVF kapsamında ilk sıralarda yer alan Norveç Varlık Fonu'nun değeri 1.186.670 milyon ABD Dolarıdır. https://www.swfinstitute.org/fund-rankings (05.06.2020)
} 
- UVF'nin yasal çerçevesi, belirlenen stratejilere uygun olmalı ve bunlara ulaşmayı destekleyebilecek standartlarda oluşturulmalıdır. Bu standartlarda yürütülecek çalışmalar fonun başarısını olumlu yönde etkileyecektir.

- UVF amaçlarını belirlemeli, açıkça tanımlanmış prosedürlere uygun olarak yönetim organlarını atamalı ve faaliyetleri üzerinde bağımsız gözetim ve denetim yapılmalıdır. Kayıran'a (2016: 69) göre de, iç denetçi yönetim kurulu tarafından atanır ve UVF yönetiminin iç düzenlemelere uyup uymadığını denetleyerek bunları yönetim kuruluna rapor eder. Uygunluk denetimi birimi ise CEO tarafindan kurulur ve UVF'nin bütün faaliyetlerinin kural ve düzenlemelere uygunluğunu araştırır.

- UVF'nin yönetim kurulu, görevlerini yerine getirmek için belli bir tasarruf hakk1 ve yeterli bir yetki ve yetkinliğe sahip olmalıdır. Şirketler de olduğu gibi fonların da amaç ve faaliyetlerini gerçekleştiren yönetim kurulu, bu görevini yerine getirirken farklı komiteler tarafından desteklenmektedir. TVF'nin yönetim kurulunda bulunan kişilerin ekonomi ve finans alanında uzman, deneyimli ve piyasalar tarafından kabul gören kişilerden oluşması gerekmektedir. Bu kapasiteye sahip olan TVF'nin Kurumsal Yönetim Komitesi, şirketin kurumsal yönetim ilkelerinin uygulanıp uygulanmadığını, eğer uygulanmıyorsa bu durumun gerekçelerini tespit etmelidir (Uysal, 2018: 49).

- UVF'nin operasyonel yönetimi, fon stratejilerini bağımsız bir şekilde ve açıkça tanımlanmış sorumluluklara uygun olarak gerçekleştirmesi için hedefleri doğrultusundaki operasyonel bağımsızlığa ve hesap verebilirliğe sahip olmalıdır.

- UVF'nin temel yasal özellikleri ve diğer devlet organları arasındaki yasal ilişkisi kamuya açıklanmalıdır. Zira devletin, hükümetlerin, ekonominin beyni olarak alacağı kararlar fonların yatırım stratejilerini etkileyebilmektedir. Örneğin, hükümetlerin alacağı yatırım kararlarının ne derece sağlıklı olacağı konusundaki endişeler, bu fonlara bakışı olumsuz yönde etkileyebileceği için kamuya bilgilendirme yapma konusunda yeterli hassasiyetin gösterilmesi gerekir.

- UVF faaliyetlerinin, ülke içi makroekonomik dengeleri etkileyeceği durumlarda, bu politikalarla tutarlılığını sağlamak için otoriteler arasında koordinasyon sağlanmalıdır. Aksi durumda gerek makroekonomik sistemdeki temel sorunların, belirsizliklerin ve gerekse de o yapıdaki mikroekonomik birimler arasındaki etkileşimlerin neden olduğu kriz beklentileri derinleşebilmektedir.

- UVF'nin finansman, geri çekme ve harcama işlemlerinin, kamuya açık düzenlemeleri, prosedürleri olmalıdır.

- UVF’nin çıktılarıyla ilgili veriler, zamanında fon yatırımcılarıyla paylaşılmalıdır.

- UVF'nin performansıyla ilgili hesap verebilirlik standardı, ilgili yasada, tüzükte, diğer kurucu belgeler veya yönetim sözleşmesinde açıkça tanımlanmalıdır.

- UVF'nin faaliyetleriyle ilgili y1llık rapor ve ekli finansal tablolar, zamanında ve kabul edilmiş ulusal/uluslararası muhasebe standartlarına göre hazırlanmalıdır. Mishkin'e (2007) göre de, işletmelerin finansal başarısızlık riskinin yönetiminde; asimetrik bilgiden, asil/vekil ilişkisinden kaynaklanacak sorunların önlenmesinde standart hale getirilmiş finansal muhasebe ve raporlama sistemlerinin kurulması ve işletilmesi önemlidir.

- UVF'nin faaliyetleri ve finansal tabloları, ulusal/uluslararası denetim standartlarına uygun bir şekilde sürekli olarak her yıl denetlenmelidir. Aynı şekilde işletmelerin kuruluş ve faaliyet süreçlerinin düzenlenmesini ve denetlenmesini sağlayacak Uluslararası Standartlar Teşkilatı'na (International Organization for Standardization - ISO) ait standartların kurulması ve işletilmesinin sağlanması gerekmektedir. Bu iki temel yapıya sahip olan işletmelerin, iç ve dış denetime açık olmaları, hem sistemik hem de sistemik olmayan risk yönetiminde başarısızlığı azaltacaktır. 
- UVF'nin profesyonel ve etik normları açıkça tanımlanmalı. Bu tanımlamaların, fonların yönetim organları, personeli tarafından bilinilirliği sağlanmalıdır.

- UVF, hedefleri doğrultusunda, üçüncü taraflarla gerçekleştireceği ilişkileri, ekonomik ve mali gerekçelere dayandırmalı; açık kural yöntemlerini takip etmelidir.

- UVF'nin yurtdışındaki faaliyetleri de, gidilen ülkelerdeki düzenleyici ve denetleyici mevzuata uygun olmalıdır. Böylece hem uluslararası kalite standartlarında mal ve hizmet üretimi; hem de finansal sermaye hareketlerindeki kara para aklamanın kontrol edilmesi mümkün olacaktır.

- UVF, haksız rekabet oluşturmamalı, imtiyazlı durumundan uzak olmalı, bundan yararlanmamalı veya hükümetin gücünden faydalanmamalıdır.

- UVF, hissedar sahipliği haklarını, hisse yatırımlarının değerini muhafaza etmenin ana unsuru olarak görmelidir. Bir UVF, sahiplik haklarını kullanmayı seçerse bunu yatırım politikasına uygun bir şekilde yapmalı ve yatırımlarının mali değerini korumalıdır.

- UVF, faaliyetlerinin risklerini tarif eden, değerlendiren ve yöneten bir çerçeveye sahip olmalıdır. Bu makro bakış mikro ölçekte de gerçekleşmelidir. Çünkü işletmelerin risk yönetiminde yeterli bilgiye sahip olmamaları veya uygulamadaki hataları, hem kendi operasyonlarında; hem de bulaşıcılık etkisiyle, ilişkili taraf ile ilişkisi olan veya olmayanlarla sorunlar yaşamalarına neden olmaktadır. Küçüközmen'e (2016: 456) göre, klasik yöntemlerle gerçekleştirilen risk yönetim teknikleri, sonuçta kurumları iflasa sürükleyebilmekte hatta sistem için bir tehdit oluşturabilecek kadar da büyüyebilmektedir. Karacan ve Savcı'ya (2011: 44) göre de, yöneticilerin, muhasebe sistemlerine gereken önemi vermemeleri, işletme yönetiminin planlamasını, kontrolünü ve değerlemesini iyi yapmamaları, üstesinden gelinemeyecek projelere eğilimli olmaları, işletmeleri mali başarısızlığa itecektir.

- UVF’nin risk yönetim standartları, güvenilir bilgiyi zamanında raporlamak için gerekli sistemleri ihtiva etmelidir. Bu standartlar, aynı şekilde bağımsız denetim fonksiyonunun uygun biçimde izlenmesini ve yönetilmesine de imkân vermelidir. Risk Yönetim Komitesi de, yatırım komitesinin üyelerinden oluşmalı ve risk yönetim çerçevesinin uygulanmasını denetlemekten sorumludur.

\section{Önemi \\ 4.2. İşletmelerin Etkin İşleyişi İçin Bağımsız Düzenleyici ve Denetleyici Kurumların}

Kamunun ekonomideki etkin ve verimli olmayan faaliyetlerinden çekilmesi için kamu işletmelerinde özelleştirme uygulamaları moda olmuştur. Özelleştirme sonrasında da piyasalarda etkin işleyişin sağlanabilmesi için piyasa ekonomisinin olmazsa olmazı hukuksal ve kurumsal altyapının oluşturulması ve işletmelerin etkin ve verimli çalışabilmesi için de bağımsız düzenleyici ve denetleyici kurumlar oluşturulmuştur. Ünlü'ye $(2011,72)$ göre, yaşamsal öneme sahip, doğal tekel konumundaki sektörlerin düzenlenmesi ve denetlenmesi için oluşturulan bu kurumlar, kamu bürokrasisi içerisinde bağımsız ve müdahalelerden uzak bir bürokrasi alanı oluşturmuşlardır. Kamu hizmetlerini yönlendirme ve işletme gücüne sahip Düzenleyici ve Denetleyici Kurumlar, görev aldıkları alanda izleme ve denetleme, regüle etme ve yaptırım uygulama yetkilerine sahip hale gelmişlerdir.

Ekonomik açıdan bu gerekliliği Perçin $(2011,334)$ çalışmasında şöyle özetlemiştir: Seçimle gelen hükümetlerin "zaman içerisinde tutarsı" politikalar izlemeleri nedeni ile verdikleri taahhütlerin güvenilir nitelikte olmadığı görülmektedir. Zaman içerisinde tutarsız politika ise gelecek için hazırlanan en iyi politikaların, uygulandığı dönemde dahi en iyi politika olmamaları olarak tanımlanmaktadır. Başka bir deyişle, seçimle gelen hükümetlerin, kamu menfaatine uygun düşmeyen çeşitli kısa vadeli politikaları, kamu menfaati ile uyumlu olan uzun vadeli politikalara tercih etmesi ve bunun sonucunda ortaya çıkan tutarsızlıklar, taahhütlerinin güvenilir olmasını 
engellemektedir. Siyasi aktörlerin bu tarz davranışlarının önüne geçilmek istenmesi de bağımsız idari otoritelerin ortaya çıkma nedenlerindendir.

$\mathrm{Bu}$ kurumların önemi, gerek özelleştirme sürecindeki uygulamalarda gerekse de krizlerde yaşanan durum Türk'ün (2014: 191) çalışmasında da şu şekilde görülmektedir: Şirketler parçalara ayrılıp satılarak ülke içinde rekabet düzeyi artırılmaya çalışılmaktayken, diğer taraftan entegre yapıları bozulan ve sermaye güçleri azalan Türk şirketlerinin küresel rekabet edebilirlik düzeyleri azaltılmaktadır. Ayrıca, özelleştirilen şirketlerin bazıları dev yabancı şirketlerin küresel entegrasyonunun bir parçası haline gelmekte ve dolayısıyla Türk şirketlerinin göreli rekabet gücü de azalmaktadır. Küreselleşmenin etkisiyle, yaşadığımız süreçte yavaş yavaş ulusal pazarlar kaybolup bölgesel ve küresel pazarlar ön plana çıkarken, şirketlerin rekabet gücündeki bu azalma trendinin devam etmesi gelecekte Türk ekonomisine telafi edilmesi mümkün olmayan zararlar verebilir. Bu noktada, gerek KİT gerek özel teşebbüs şirketi, küresel ölçekte rekabet etme potansiyeline sahip tüm Türk şirketlerinin desteklenmesi, yurtdışında yatırım yapmalarının ve şirket satın almalarının teşvik edilmesi gerektiği düşünülmektedir.

İşletmelerin başarılı kriz yönetimini gerçekleştirebilmeleri veya kendi aralarındaki yıkıcı rekabetin önlenebilmesi için piyasaların düzenlenmesi ve denetlenmesiyle görevli kurumlara önemli işler düşmektedir. İdari teşkilat içinde diğer kurum ve kuruluşlara göre daha yakın bir geçmişte ortaya çıan ve Türkiye'de 80 'li yıllardan itibaren oluşturulan bu düzenleyici ve denetleyici kuruluşlar, kamu sektörünün de işleyişinde etkin bir rol oynamaktadır (Azimli ve Çilingir, 2018: 11). Bu çerçevede, söz konusu kurumların düzenlemelerindeki temel yaklaşım, yıkıcı rekabetin olmadığı ve tüketicinin korunduğu kapsayıcı bir piyasa mekanizmasının oluşturulması ve sürekliliğinin sağlanması olmalıdır.

Dolayısıyla bu bakış açısına sahip tüm sektörlerdeki ana düzenleyici ve denetleyici yapılara önemli görevler düşmektedir. Onların yapacağı düzenlemeler yönlendiriciliğinde, işletmelerin kuruluş izinlerinin verilmesi, risk yönetim modellerinin geliştirilebilmesine yardım ve uygulanmasının teşvik ve takibinin yapılması, bağımsız düzenleyici ve denetleyici kurumların taşra yapılanmalarınca sağlanabilmelidir. Gerek mevzuat gerekse de uygulamanın şekli hakkındaki temel rehber uluslararası standartlar olmalıdır. Örneğin işletmelerin kuruluş ve faaliyet süreçlerinin düzenlenmesini ve denetlenmesini sağlayacak ISO gibi standartlar; finansal sektör için Basel düzenlemeleri; işletmelerin mali başarısızllk riskinin kontrol ve yönetiminde, standart hale getirilmiş finansal muhasebe ve raporlama sistemlerinin kurulması ve işletilmesi gerekmektedir. Bunun için de temel koşul, tüm işletmelerde/kurumlarda iç ve dış kontrol süreçlerinin tanımlanması ve işletilmesi zorunlu olmalidır.

\section{Sonuç}

Cumhuriyetin ilanından sonra Türkiye'de, kalkınmanın devlet eliyle gerçekleştirilmesinin gerekliliği olarak gündeme gelen KİT'ler, dönemin iktisadi yapıdaki zorunlulukları, özelikle finansal ve fiziksel sermaye stokundaki yetersizlikleri nedeniyle kurulmaya başlamıştır. 1960'lı yılarda da, ithal ikameci kalkınma stratejisinin uygulanmasında önemli boşluğu dolduran KíT'lerin önemli başarıları olmuştur. Fakat bir dönem devletin ekonomiye müdahalesinin haklı gerekçelerine karşın uygulama sonuçlarındaki başarının devamlılı̆ğ çeşitli nedenlerle sağlanamamıştır. Dolayısıyla kamu işletmeciliğinin tasfiyesine karar verilmiş veya kamunun müdahale şekilleri değişmiştir. Aslında yeri geldiği zaman bu değişimlerin yapılması gerekmektedir. Bunda da temel amaç piyasa ve kamu otoritesi birbirini dışlamamalı yani müdahaleler sınırsız olmamalıdır. Fakat müdahaleler doğru zamanda, tam yerinde ve uygun bir şekilde yapılmalıdır. Böylece kamunun önderliğinde, her alanda başlatılacak olan mali disiplini sağlayıcı şeffaflık uygulamaları, hem kamu gelirlerini artırabilecektir; hem de kamu ve özel sektör işletmelerine model olabilecektir. Bu amaçlara ulaşabilmek için de tabii ki, yeri geldiğinde başarılı olamayan, profesyonel yönetimin olmadığı kamu işletmelerinde özelleştirme yöntemleri kullanılabilir. Fakat bunun için de, piyasa ekonomisinin olmazsa olmazı, 
hukuksal ve kurumsal altyapı oluşturulmalıdır. Bu yapıların etkin çalıştı̆g durumda, kamu-özel sektör işbirliği yöntemleri, doğru yüklenicinin seçilmesi, yüklenici ile kamu idaresi arasındaki risk paylaşımının doğru yapılması ve kamu garantilerinin etkin bir şekilde kullanılması durumunda, kamu yatırımlarının finansmanı noktasında devlete çok büyük bir rahatlık sağlayacaktır.

Kamu-özel sektör işbirliğinde bu şekildeki başarılı projelere imza atılabilmesi için Türkiye'nin bu anlamdaki birikmiş olan kurumsal hafizası özellikle, Özelleştirme İdaresi Başkanlığı, Tasarruf Mevduatı Sigorta Fonu, Bankacılık Düzenleme ve Denetleme Kurumu, Rekabet Kurumu gibi yapıların tecrübeleri, Türkiye Varlık Fonu bünyesindeki projelerin tesisinde, çalıştırılmasında dikkate alınmalıdır. Zira küreselleşmenin de tetiklediği belirsizlik ve yıkıcı rekabet ortamı, hem finans kuruluşlarında hem de işletmelerde operasyonların yönetimini giderek zorlaştırmaktadır.

Ticaret savaşları, uluslararası göçler, teknolojik gelişmeler, küresel felaketler ve salgınların ortaya çıkardığı ekonomik zorunluluklar nedeniyle, kamuya duyulan ihtiyaç artmaktadır. Fakat bu yapıların hantal olmaması gerekmektedir. Çünkü önceki dönemlerdeki KíT ve benzeri işletmelerdeki yönetim anlayışı günümüzde artık mümkün değildir. Bu çerçevede, tüm sektörlerdeki düzenleyici ve denetleyici kurumlara önemli görevler düşmektedir. Onların yapacağı düzenlemeler kılavuzluğunda, işletmelerin kuruluş izinlerinin verilmesi, risk yönetim modellerinin geliştirilebilmesine yardım ve uygulanmasının teşvik ve takibinin yapılması bağımsız düzenleyici ve denetleyici kurumların taşra yapılanmalarınca sağlanabilmelidir.

$\mathrm{Bu}$ süreçteki oluşumlarda, gerek mevzuat gerekse de uygulamanın şekli hakkındaki temel rehber uluslararası standartlar olmalıdır. Santiago İlkelerini esas alarak UVF'nin belirlediği standartlar hem TVF'nin hem de onun portföyündeki işletmelerin kuruluş ve faaliyet süreçlerinin düzenlenmesine ve denetlenmesine olanak sağlamalıdır. Bu düzenlemelerin yanı sıra ISO gibi standartlar, finansal sektör için Basel düzenlemeleri, bu konuda destekleyici bir işleve sahiptir. Burada sürekliliğin sağlanması için temel koşul, tüm işletmelerde/kurumlarda iç ve dış kontrol, denetim ve gözetim süreçlerinin tanımlanması ve işletilmesi olmalıdır. Sonuç olarak söylenebilir ki, bu altyapıların kurulduğu ve çalıştırıldığı bir ekosistemde, TVF’nin işletmecilik şekli özel sektöre de model olabilecektir ve/veya olmalıdır.

\section{Kaynakça}

Atiyas, İ. ve Oder, B. (2008). Türkiye'de Özelleştirmenin Hukuk ve Ekonomisi, Türkiye Araştırma Vakfi Yayını (TEPAV).

Çetinkaya, Ş. (2017). Dünyada Ulusal Varlık Fonu ve Türkiye Varlık Fonu Üzerine Swot Analizi, Uluslararası Sosyal Bilimler Akademik Araştırmalar Dergisi, Vol. 1, 30-39. https://doi.org/10.18354/esam.336762

Azimli Çilingir, G. (2018). Türkiye'deki Düzenleyici ve Denetleyici Kuruluşların İdari Yapı İçerisindeki Rolü, Osmaniye Korkut Ata Üniversitesi İktisadi ve İdari Bilimler Fakültesi Dergisi, Vol. 2, 1-13. https://doi.org/10.25287/ohuiibf.536595

Dama, N. (2018). Sosyal Koruma Sisteminde Hak ya da Risk Olarak Erken Emeklilik, Seta Perspektif, 214.

Danık, G. (2019). Uluslararası Varlık Fonu Tecrübelerinden Türkiye Varlık Fonuna Bakış, [Yayınlanmamış Yüksek Lisans Tezi]. Bilecik Şeyh Edebali Üniversitesi, Sosyal Bilimler Enstitüsü.

Demirtaş, Ö., Karaca, M. ve Biçkes, M. (2017). Başarılı Girişimciliğin Perde Arkasındaki Güçler: Bazı İnsanlar Neden Girişimci Olarak Diğerlerinden Daha Başarılıdır?, (Gen. Ya. Yön. Yusuf Ziya Aydoğan), Eğitim Yayınevi. 
Durdu, M. (2018). Türkiye Varlık Fonu İçin Bir Uygulama Örneği: Singapur Temasek Holding, Necmettin Erbakan Üniversitesi Hukuk Fakültesi Dergisi, Vol. 1, 74-92.

Erengül, B. (1989). “Özelleştirmede Tezler ve Karşı Tezler”, Dış Ticarette Durum, S.17, 18-19.

Görgün, S. (1973). Maliye Politikası, İ.Ü. Yayın No: 1823, Çağlayan Basımevi.

IFSWF (2020). Turkiye Wealth Fund approved for membership of the IFSWF. https://www.ifswf.org/general-news/turkiye-wealth-fund-approved-membership-ifswf

IWG (2008). Sovereign Wealth Funds Generally Accepted Principles and Practices "Santiago Principles", International Working Group of Sovereign Wealth Funds, October. https://doi.org/10.2139/ssrn.2316123

Kocabaşoğlu, U. (2001). Türkiye İş Bankası Tarihi, İş Bankası Kültür Yayınları.

Karacan, S. ve Savcı, M. (2011). Kriz Dönemlerinde İşletmelerin Mali Başarısızlık Nedenleri. Kocaeli Üniversitesi Sosyal Bilimler Dergisi, 2011; (21), 39-54.

Karagöl, E. ve Koç. Y. (2016). Dünyada ve Türkiye'de Varlık Fonu, SETA Analiz Dergisi, Sayı: $169,7-24$.

Kayıran, M. (2016), Türkiye Varlık Fonu'nun Kuruluş Amaçları ve Yapısı Üzerine Bir Değerlendirme, Eğitim Bilim Toplum Dergisi, C:14, 55-90. https://doi.org/10.20860/ijoses.571367

Küçüközmen, C.C. (2016). “Bankacılık ve Risk Yönetimi”, Bankacılığın El Kitabı, (Editörler: N.Oğuzhan Altay ve Diğerleri), Akademi Consulting \& Training, Ankara, 441-456.

Mishkin, F.S. (2007). The Economics of Money, Banking, and Financial Markets, Eighth Edition, Pearson addison Wesley.

ÖİB (2020). Özelleştirme Fonu Kaynak-Kullanım Tablosu. https://ms.hmb.gov.tr/uploads/sites/6/2019/11/fongelirgiderekim.pdf

Ökçün, G.A. (1968). Türkiye İktisat Kongresi, 1923-İzmir, Haberler, Belgeler, Yorumlar, Ankara Üniversitesi Siyasal Bilgiler Fakültesi Yayınları. https://doi.org/10.35250/sks.02.2019.01.05

Pamuk, Ş. (2012). Osmanlıdan Cumhuriyete Küreselleşme, İktisat Politikaları ve Büyüme, Türkiye İş Bankası Kültür Yayınları Genel Yayın: 1611, B.3.

Pamuk, Ş. (2014). Türkiye’nin 200 Yıllık İktisadi Tarihi “büyüme, kurumlar ve bölüşüm”, Türkiye İş Bankası Kültür Yayınları Genel Yayın: 2910.

Perçin, Ö. (2011). Bağımsız İdari Otoriteler, İnönü Üniversitesi Hukuk Fakültesi Dergisi, Vol. 2, 325-345. https://doi.org/10.1501/hukfak_0000000352

SWFI (2020). Norges Bank Investment Management (Norway GPFG). https://www.swfinstitute.org/profile/598cdaa60124e9fd2d05b9af

Tan, T. (1992). KìT'lerin Özelleştirilmesi ve Sorunlar, Amme İdaresi Dergisi, 25 (1), 27-64.

Tezel, Y. S. (1986). Cumhuriyet Döneminin İktisat Tarihi, Yurt Yayın No.4, B.2.

Türk, Y. Z. (2014). Türkiye'de Özelleştirme Uygulamalarının Analizi, Uzmanlık Tezi, T.C. Kalkınma Bakanlığı Yıllık Programlar ve Konjonktür Değerlendirme Genel Müdürlüğü, Yayın No: 2885.

Türkoğlu Karacaova, E. N. (2019). Türkiye Cumhuriyeti’nin Yeni Hukuki Teknolojisi: Usule Bağlı Olmayan Bir Özelleştirme Yöntemi Olarak Türkiye Varlık Fonu. ViraVerita E-Dergi, Sayı 10, 1-29. 
Ünlü, U. (2011). Kamu Hizmetlerinin İşletilmesi, Denetişim, S.8, 68-73).

Uysal, S. (2018). Ulusal Varlık Fonları ve Türkiye Varlık Fonu, Nobel Yayınları. https://doi.org/10.14784/marufacd.460664

Wade, G. R. (1989). Özelleştirme Sorunları: Karşılaştırılmalı Bir Yaklaşım, Özelleştirme Yöntemleri ve Uygulama Sorunları, Yased Ya.No.35.

Yazıcı, R. (2017), Türkiye'deki KİT'lerin Özelleştirme Tecrübelerinden Varlık Fonu Kurulmasına Bakış, Journal of Strategic Research in Social Science, 3(3), 89-100, https://doi.org/10.26579/josress-3.3.6 